Historia Slavorum Occidentis

2021, nr 4 (31)

ISSN 2084-1213

DOI: $10.15804 /$ hso210401

\author{
Katarzyna Balbuza (Poznań)
}

ORCID: 0000-0002-3105-3792

\title{
Roman coin finds from vicinity of Ostrów Lednicki. Lednica Project "Together to Save the Heritage" (2018-2022)
}

Keywords: coin hoards, Roman coins, period of Roman influence, Lednica

Słowa kluczowe: znaleziska monetarne, monety rzymskie, okres wpływów rzymskich, Lednica

Abstract: The article presents finds of Roman coins from the area located in the immediate vicinity of Ostrów Lednicki island, found in the years 2018-2021.

Lednica Project "Together to Save the Heritage" (2018-2022) revolves around prospective metal detecting research initiated and carried out by archaeologists from the Museum of the First Piasts at Lednica, "Gniazdo" Wielkopolska Exploration and Historical Group, Lidia Żuk, Ph.D., from the Faculty of Archaeology at Adam Mickiewicz University in Poznań and Mikołaj Kostyrko, Ph.D., from the Institute of Archaeology, the University of Bamberg (Institut für Archäologische Wissenschaften, Denkmalwissenschaften und Kunstgeschichte). ${ }^{2}$ The excavation area in-

1 The article is an extended version of a communiqué published in Polish in Studia Lednickie 19 (2020), p. 261-273 and includes, a.o. the results of the metallographic analysis of coins and a new one, recently excavated coin.

2 A report on the course of works carried out as part of the project: M. Kostyrko, A. Kowalczyk, L. Żuk, Projekt Lednica „Razem dla ratowania zabytków”. Sprawozdanie za rok 2018 
cludes the southern and central parts of Lake Lednica, located in the immediate vicinity of Ostrów Lednicki island. The goal of the research is to identify the local cultural landscape and juxtapose the resulting picture with the advancement of the related research. The involved scientists also intend to protect the archaeological heritage from amateur detectorists (in most cases, artefacts excavated in this way are kept beyond archaeological registration and thus incur a huge loss to science ${ }^{3}$ ), from the damaging effect that strongly invasive chemicals used in agriculture could have on the coins and from the potential investment and construction plans for the area which in the future may hamper archaeological excavations if not make them downright impossible. Field work carried out by both the archaeologists ${ }^{4}$ and trained amateur detectorists include historical objects covered by the earth up to $30 \mathrm{~cm}$. For the research purposes, the area has been divided into large analytical squares $\left(1 \times 1 \mathrm{~km}^{2}\right)$ to be explored; each square is further divided into four hundred smaller analytical squares $(50 \times 50 \mathrm{~m})$ where the finds are catalogued. The detectorists' passages, the venues where the artefacts were found, the excavation log and the artefacts catalogue are registered and documented in QGIS software. The process of obtaining coins by archaeologists has been revolutionised by using metal detectors. Use of this equipment in the context of discovering antique coins marks considerable progress in research into the local, archaeological and cultural landscape of the time of the Przeworsk culture and the early pre-modern human migration as well as saving historical objects. As part of the Lednica project "Together to Save the Heritage", in land prospection the following detecting equipment has been used: XP Deus, Minelab Equinox, Garrett and Rutus.

(Lednica Project "Together to Save the Heritage". A Report on Work Undertaken in 2018), Studia Lednickie 18 (2019), p. 323-333.

3 Various scientists have made attempts at preventing it. See, for example, research and initiatives launched in Poland by Arkadiusz Dymowski. A. Dymowski, Znaleziska monet rzymskich rejestrowane $w$ pierwszych latach XXI wieku. Aspekty źródłoznawcze, Zielona Góra 2011; idem, Nummi serrati, bigati et alii. Coins of the Roman Republic in East-Central Europe North of the Sudetes and the Carpathians, Warsaw 2016.

4 The team in charge of archaeological surface studies consists of Andrzej Kowalczyk (manager) Arkadiusz Tabaka, Danuta Banaszak, Paweł Sankiewicz, Daniel Tomczyk, Alina Ewertowska, Mikołaj Kostyrko, Lidia Żuk, Anna Broda, Krystian Sobkowiak, Barbara and Grzegorz Mazurkiewicz, Katarzyna and Maciej Michalewicz, Krzysztof Woźny, Wojciech Ziemkowski, Jakub Ciesielski, Izabela Długa, Łukasz Czajkowski, Dawid Gembara, Marek Pieczyński, Szymon Michalak, Paweł Ziętarski, Sławomir Kurek, Sławomir Sobociński, Paweł Mueller and Zbigniew Góral. The team was appointed on 23 III 2018 by Prof. Andrzej M. Wyrwa, Ph.D., director of the Museum of First Piasts at Lednica. 
In the course of field works commenced in 2018, eleven Roman coins have been discovered (Fig. 1 and Appendix 2). These are single finds and, with two exceptions, lying in close vicinity to each other (Fig. 2 - Map 1). ${ }^{5}$ As the metallographic analysis shows (Appendix 1 - Tables 1-2), the only denomination has been the denarius, main type in the Roman monetary standard minted at Rome. Due to the coins' significant corrosion, in three cases further investigations are hard to conduct; these may be the limes denarii or fourrées (possibly an anima subaerata). ${ }^{6}$ All the identifiable specimens were issued during the reign of the Nerva-Antonine dynasty. The oldest coins come from the time of Trajan, ${ }^{7}$ the youngest is related to the reign of Marcus Aurelius. ${ }^{8}$ Two denarii were issued in the time of Hadrian, ${ }^{9}$ three others in the time of Antoninus Pius. ${ }^{10}$ Two specimens are beyond identification. ${ }^{11}$ The coins come from the layers of the Przeworsk culture (a settlement) or the early-medieval culture (a settlement, a grave field). The area of the prospective metal detecting research is a part of a large settlement complex; its most impressive remains go back to the early Middle Ages. ${ }^{12}$ Nearby, an island (Ostrów Lednicki) on lake Lednica hosts and archaeological site with remains of a settlement centre of state rank. During the reign of Mieszko I (approx. 960-992) and Bolesław I the Brave (992-1025), it was among the most important defence and administration centres in Poland. In a stronghold on the island, surrounded by a fortification, are remains of a pre-Romanesque architectural complex consisting of a palace and church from the time of Mieszko I. ${ }^{13}$

5 RIC III, Ant. Pius 204 (B3_140-1 = Lednica 5); C2_250-6 = Lednica 11.

6 RIC II, Trajan 60 (?) (C2-222-6 = Lednica 1); RIC III, Ant. Pius 61c (C2_285-4 = Lednica 6); $\mathrm{C} 2-324-7=$ Lednica 11.

7 RIC II, Trajan 60 (?) (C2-222-6 = Lednica 1); RIC II, Trajan 52 (C2-265-73 = Lednica 2). 8 RIC III, Marcus Aurelius (Faustina II) 710 (C2-324-1 = Lednica 8); RIC III, Marcus Aurelius (Lucilla) 788 (C2-283-5=Lednica 9).

9 RIC II, Hadrian 256 (C2-282-19 = Lednica 3); RIC II, Hadrian 230a (C2-302-15 = Lednica 4).

10 RIC III, Ant. Pius 204 (B3-140-1 = Lednica 5); RIC III, Ant. Pius 61c (C2-285-4 = Lednica 6); RIC III, Ant. Pius 153c (C2-285-78 = Lednica 7).

11 C2-324-7 = Lednica 10; C2-250-6 = Lednica 11.

12 Since 16 IX 1994, Ostrów Lednicki has been on the list of historical monuments, Ordinance of the President of the Republic of Poland of 8 IX 1994 - recognition of historical monuments: Monitor Polski 50 (1994), item 421: http://isap.sejm.gov.pl/isap.nsf/DocDetails.xsp?id=WMP19940500421 [accessed: 25 X 2021].

13 Ostrów Lednicki. Rezydencjonalno-stołeczny ośrodek pierwszych Piastów, eds. by Z. Kurnatowska, A. Wyrwa, Warsaw 2016: the status of the latest research and reference to literature on the subject. 
Several years ago, within the Lednica project interdisciplinary archaeological excavations, a part of the area of the prospective metal detecting research was explored. More specifically, it was Dziekanowice 22 site from which a majority of the coins published in this report come ${ }^{14}$. As part of the excavations, conducted in an early-medieval grave field dated at the second half of the $11^{\text {th }}$ to the $13^{\text {th }}$ centuries, seven Roman coins have been registered and identified; six of them were excavated from early-Piast, early medieval skeletal graves. One of them, a subaeratus of Antoninus Pius, was outside the grave. ${ }^{15}$ In the case of coins found in the graves, they include three denarii subaerati and three silver denarii. The coins come from the $2^{\text {nd }}$ century and were minted during the time of the Nerva-Antonine dynasty (Trajan, Hadrian, Antoninus Pius, Marcus Aurelius). ${ }^{16}$ One denarius comes from the times of Septimius Severus. ${ }^{17}$ The occurrence of Roman coins in a sepulchral context of the early Middle Ages in Poland ${ }^{18}$ is attributed to their religious function. Possibly,

14 The results of the research together with an in-depth analysis published in the volume entitled Nummus bonum fragile est. Groby z monetami wczesnośredniowiecznego cmentarzyska $w$ Dziekanowicach, vol. I-II, ed. by J. Wrzesiński, Lednica 2016 (Fontes. Biblioteka Studiów Lednickich, series B1, vol. 7: 1-2).

15 Inventory no. 29/07. See S. Suchodolski, Obol zmartych (monety i pieniądz kruszcowy) na cmentarzysku $w$ Dziekanowicach, stan. 22, [in:] Nummus bonum fragile est, pp. 177, 180. 16 RIC II, Trajan 33 (grave 16/07, inventory no. 17/07: a cut half of Trajan's denarius subaeratus; the coin was on the deceased's temple); RIC II, Hadrian 94=RIC II.3, Hadrian 223-227 (Hadrian's denarius subaeratus from 119-122; grave 72/99, inventory no. 129/99; the coin was discovered to the right of the waist); RIC II, Hadrian 77-78=RIC II.3, Hadrian 536-547 (Hadrian's denarius from 119-138; grave 85/02, inventory no. 118/02; the coin was found next to the left femur); RIC III, Antoninus Pius 58 (Antoninus Pius' denarius subaeratus from 139; grave 14/98, inventory no. 72/98; the coin was found next to the right foot); RIC III, Marcus Aurelius 475 a (Marcus Aurelius' denarius of a Caesar; grave 11/04, inventory no. 16/04; the coin was found on the level of the right hand).

17 RIC IV, Septimius Severus 118 (Septimus Severius' denarius from 197-198; grave 68/07, inventory no. 57/07). The denarius was found in a grave of a child who died at the age of $2-3$ (the coin was in the lower jaw). See J. Wrzesiński, Archeologia dziekanowickich grobów z monetami, [in:] Nummus bonum fragile est, p. 148; S. Suchodolski, Obol, p. 171, no. 144.

18 J. Wrzesiński, Archeologia dziekanowickich grobów z monetami, [in:] Nummus bonum fragile est, p. 15. About Roman coins in the context of graves see S. Nielsen, Roman Denarii in Denmark - an Archaeological Approach, Nordisk Numismatisk Årsskrift 88 (1987), p. 148; H. Steuer, Obolus, [in:] Reallexikon der Germanischen Altertumskunde 21 (2002), p. 498-515. See also A. Zapolska, Denary rzymskie znajdowane w kontekstach wczesnośredniowiecznych na ziemiach polskich, Wiadomości Numizmatyczne 51 (2007), p. 151, 159, 161, no. 6 (in the context of coins discovered in Dziekanowice). 
they served as devotional objects. ${ }^{19}$ As Stanisław Suchodolski has aptly noted, the coins could have represented a part of a treasure hidden there in ancient times and discovered in the Middle Ages. This way the antique coins must have been seized by the inhabitants of Dziekanowice and the surrounds; later on, they assumed the function of the so-called Charon's obol. According to S. Suchodolski, that was how they ended up in the graves. ${ }^{20}$ Quite possibly, the history of the coins excavated as part of the Lednica project "Together to Save the Heritage", on Dziekanowice 22 site (i.e. in the grave field and the early medieval settlement), could be interpreted in a similar way. Most probably, they come from the same source i.e. the mentioned treasure of Roman coins found in the Middle Ages and were a part of the early-medieval grave goods, damaged in the course of agricultural work. That would explain the dispersion of the coins. Just like the earlier mentioned specimens found in the course of regular archaeological work, the coins are quite timeworn. What is more, they are the only denarii - some of them limes denarii, some are subaerati. Just as it was the case with the denarii excavated in the grave field, with a single exception (Septimius Severus' denarius), they are coins from the $2^{\text {nd }}$ century, from the times of the Nerva-Antonine dynasty. Roman coins as parts of treasures discovered in the early-medieval context are nothing new in Poland while Wielkopolska together with Pomerania are regions enjoying the biggest number of the artefacts. The treasures of denarii from the $2^{\text {nd }}$ century (the Nerva-Antonine dynasty) are also among the most frequent. ${ }^{21}$

At this stage of research, it is difficult to make unambiguous conclusions about the Roman coins discovered during the Lednica project "Together to Save the Heritage". They come from mixed layers, secondary context, and therefore have no historical setting. They were discovered in the southern part of site 22 in Dziekanowice, i.e. in an area beyond the reach of the cemetery. Perhaps they have something to do with it, but more likely they were part of a scattered Roman treasure. Of great importance for their interpretation are other finds obtained during the surface survey carried out as part of the Lednica project "Together to Save the Heritage" in

19 J. Wrzesiński, Archeologia, p. 79. See Ł. Miechowicz, By pewniej i szybciej przenióst się na tamten świat... Pieniądz jako element praktyk pogrzebowych na Mazowszu, Podlasiu i w Małopolsce w średniowieczu i czasach nowożytnych, [in:] "In silvis, campis... et urbe". Średniowieczny obrzadek pogrzebowy na pograniczu polsko-ruskim, eds. by S. Cygan, M. Glinianowicz, P.N. Kotowicz, Rzeszów-Sanok 2010, p. 350.

S. Suchodolski, Obol, p. 180.

21 See A. Zapolska, Denary rzymskie, tables 1-2, p. 168-169. 
the years 2018-2022, especially several dozen Roman-era fibulae (brooches), as well as other monuments attributed to the period of Roman influences and coming from other archaeological research carried out earlier in this and nearby areas and analysed since the $1960 \mathrm{~s}^{22}$ Further research round here may bring new results that will allow for new interpretations of the nature of the presence of Roman-era communities in this area.

\title{
Appendix 1
}

\section{A Metalographic Analyse ${ }^{23}$}

The energy-dispersive-X-ray-fluorescence (EDXRF) portable spectrometer Tracer $\mathrm{Vg}$ (Brucker, USA) has been used. The spectrometer is characterized by the following parameters: the current range $6 \mathrm{kV}-50 \mathrm{kV}$, the amperage $5 \mu \mathrm{A}-200 \mu \mathrm{A}$, graphene $1 \mu \mathrm{m}$ detector (resolution $<140 \mathrm{eV}$ ). In presented studies two steps of measurements have been applied using $3 \mathrm{~mm}$ collimator: (i) $40 \mathrm{kV}$, Ti $25 \mu \mathrm{m}$ and $\mathrm{Al}$ $300 \mu \mathrm{m}$ filter (ii) $5 \mathrm{kV}$, no filter. The built-in calibration for alloys analysis has been used for quantitative determinations. During all analysis, the spectrometer has been mounted in the desktop stand. Coins were analysed for the three positions of the radiation beam: in the centre and at the edge of the tested artefact. The obtained six results make it possible to determine both the composition of the coin and possible changes in composition (e.g. caused by counterfeiting).

\section{Table 1 Analysis of silver coins}

\author{
Table 2 \\ Analysis of non-silver coins
}

\footnotetext{
22 On the hitherto archaeological research conducted in this area since the 1960s, during which various Roman-era finds were discovered, with a discussion of the results of these studies see recently M. Wawrzyniak, Zbiór fibul z okresu wpływów rzymskich pozyskanych $w$ trakcie badań powierzchniowych zrealizowanych $w$ ramach „Projekt Lednica. Razem dla ratowania zabytków" w latach 2018-2022, Studia Lednickie XX, 2021 (in print).

23 For the metallographic analysis I would like to thank to Przemysław Niedzielski (Faculty of Chemistry, University of Adam Mickiewicz in Poznań).
} 
Table 1

Analysis of silver coins

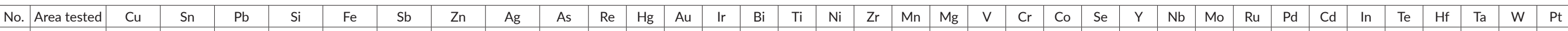

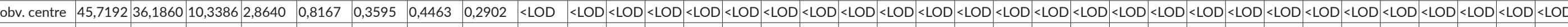

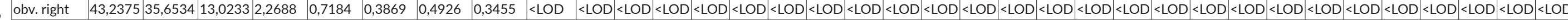

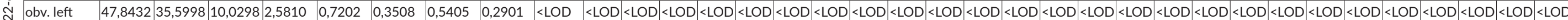

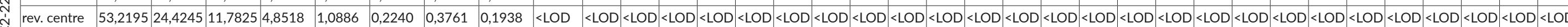

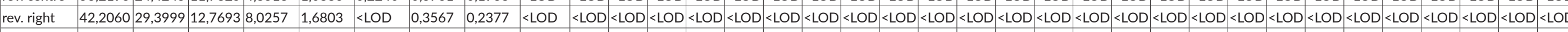

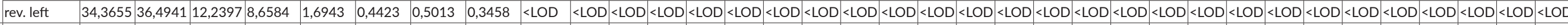

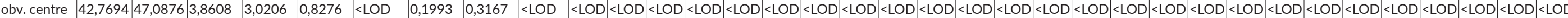

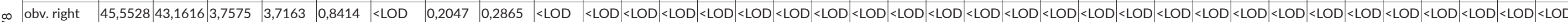

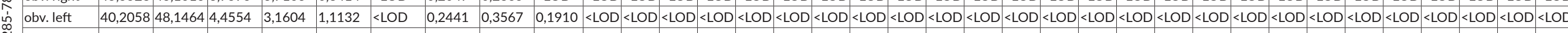

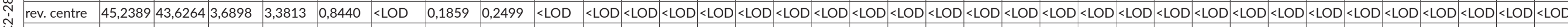

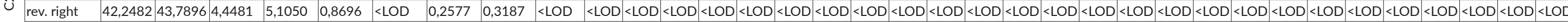

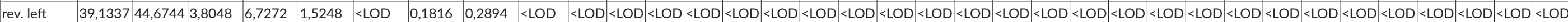




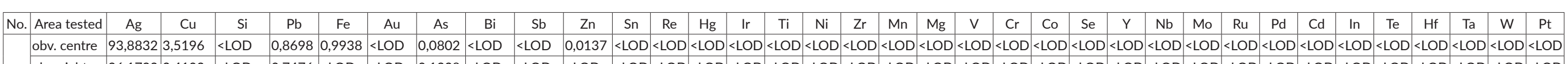
obv. right $96,17922,4103<\angle O D \quad 0,7476<L O D<L O D \quad 0,1338<L O D<L O D<L O D<L O D<L O D<L O D<L O D<L O D<L O D<L O D<L O D<L O D<L O D<L O D<L O D<L O D<L O D<L O D<L O D<L O D<L O D<L O D<L O D<L O D<L O D<L O D<L O D<L O D$

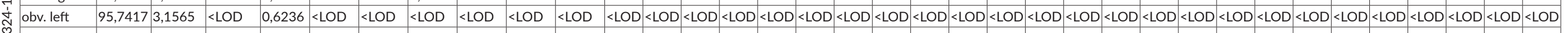

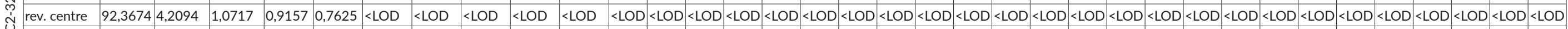
rev. right $\quad 89,77167,6537<\angle O O D \quad 0,93990,8506<L O D \quad 0,1328<L O D \quad<L O D<L O D \quad<L O D<L O D<L O D<L O D<L O D<L O D<L O D<L O D<L O D<L O D<L O D<L O D<L O D<L O D<L O D<L O D<L O D<L O D<L O D<L O D<L O D<L O D<L O D<L O D<L O D$ rev. left $93,75652,3931 \quad 1,1526 \quad 0,81531,2621<L O D \quad<L O D \quad \angle L O D<L O D<L O D \quad<L O D<L O D<L O D<L O D<L O D<L O D<L O D<L O D<L O D<L O D<L O D<L O D<L O D<L O D<L O D<L O D<L O D<L O D<L O D<L O D<L O D<L O D<L O D<L O D<L O D$

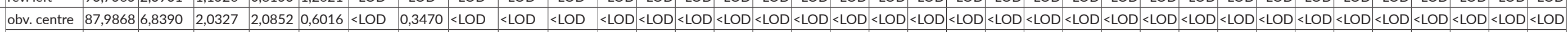

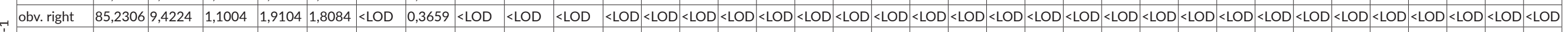

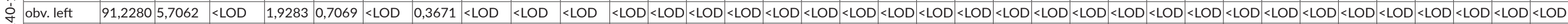

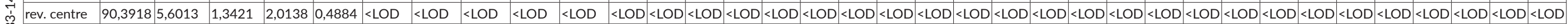
rev. right $94,40003,2315<L O D \quad 2,1028<L O D<L O D \quad 0,1573<L O D \quad<L O D<L O D \quad<L O D<L O D<L O D<L O D<L O D<L O D<L O D<L O D<L O D<L O D<L O D<L O D<L O D<L O D<L O D<L O D<L O D<L O D<L O D<L O D<L O D<L O D<L O D<L O D<L O D$

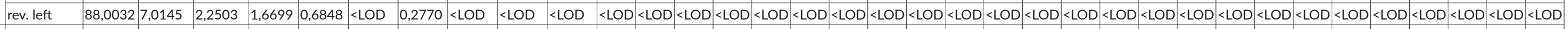

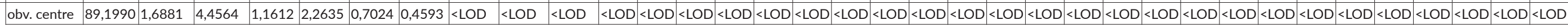

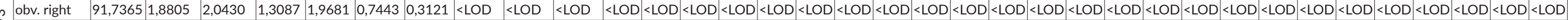

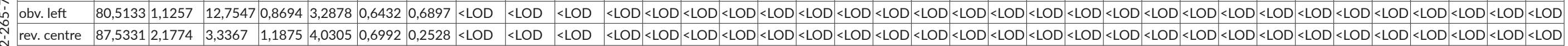

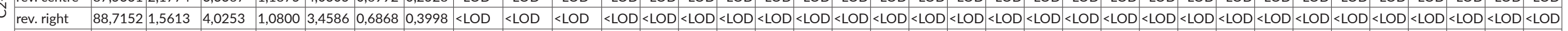

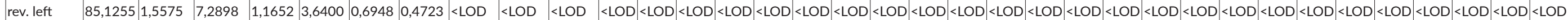
obv. centre $89,07950,8241<\angle O D \quad 1,2892 \quad 2,4668 \quad 1,2874 \quad 1,4970<L O D<L O D \quad 0,1190<L O D<L O D<L O D<L O D<L O D<L O D<L O D<L O D<L O D<L O D<L O D<L O D<L O D<L O D<L O D<L O D<L O D<L O D<L O D<L O D<L O D<L O D<L O D<L O D<L O D$

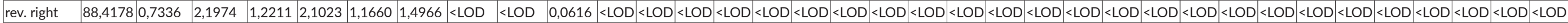

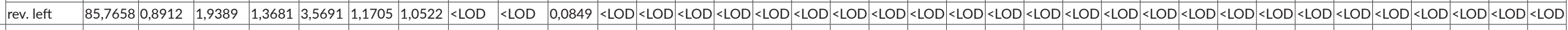

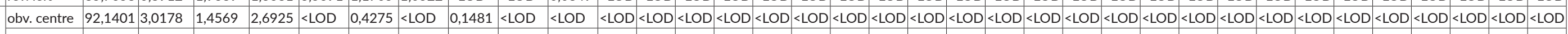

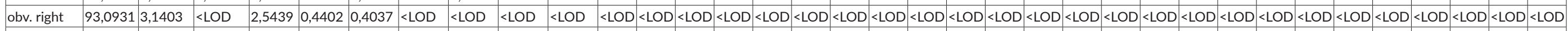

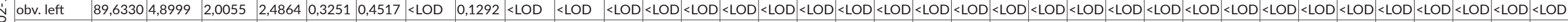

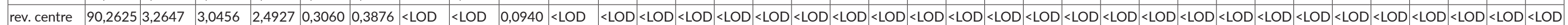

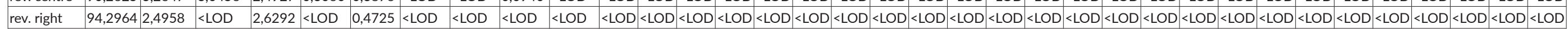

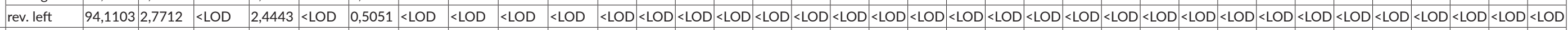

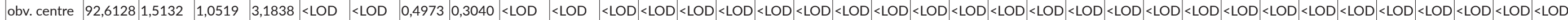

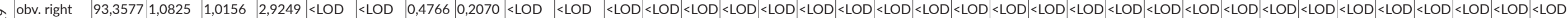

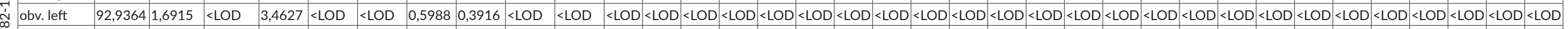

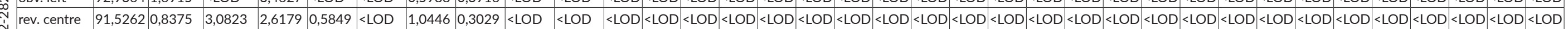

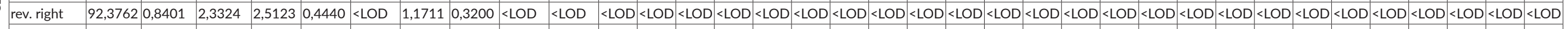

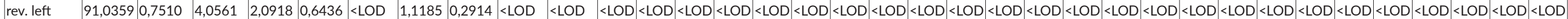

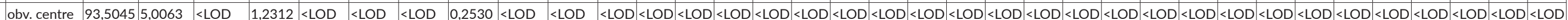

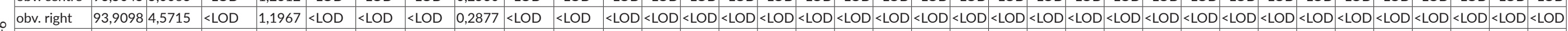

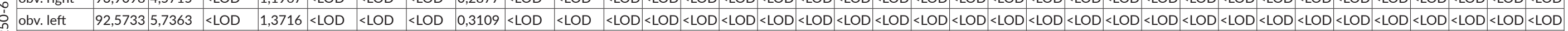

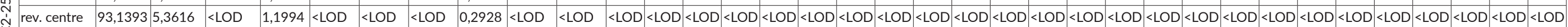

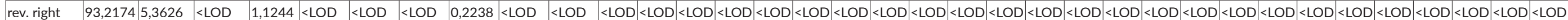

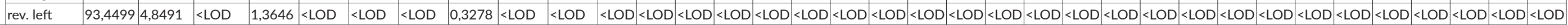

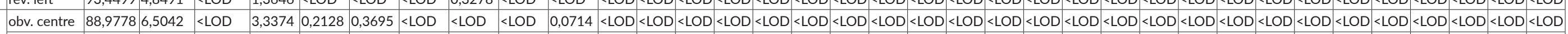

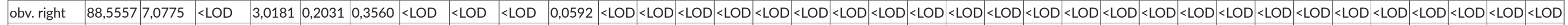

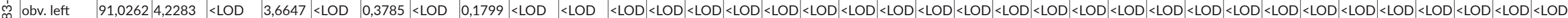

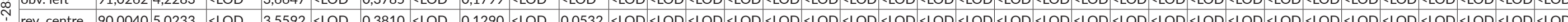

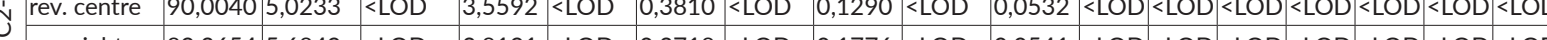

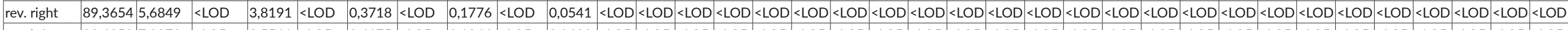

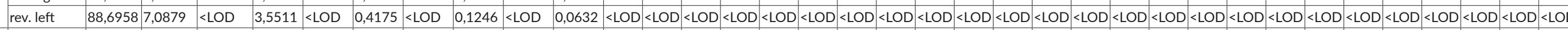

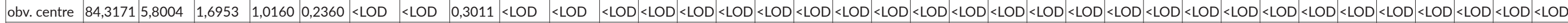

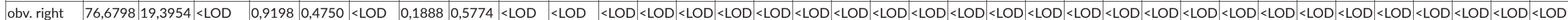

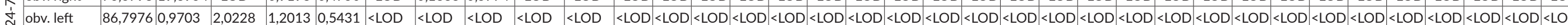

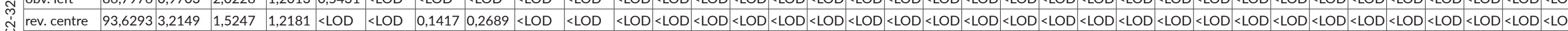

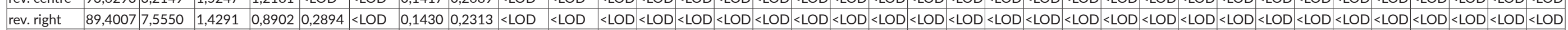

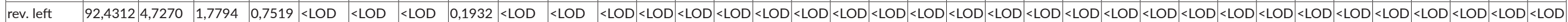




\section{Appendix 2}

\section{A Catalogue of Excavated Roman Coins - Dziekanowice (2018-2020)}

Lednica $1=\mathrm{C} 2-222-6$

Trajan, a limes denarius / denarius subaeratus (anima?), mint: limes (?), $\mathrm{AD} 101-102(?)$

Obverse: [IMP(erator) CAES(ar) NER]VA TRAIAN(us) AVG(ustus) GERM(anicus)]: Trajan's head, laureate, right

Reverse: [P(ontifex) M(aximus) TR(ibunicia) P(otestate)] CO(n)S(ul) I[III P(ater)] P: Victoria walking to the left, holding a wreath and a palm leaf Diameter: $17.1-18.3 \mathrm{~mm}$

Weight: $2.08 \mathrm{~g}$

Axis: $6 \mathrm{~h}$

Excavation method: prospective metal detecting research

Location (village/log ref. no.): Dziekanowice /7/2. AZP-50-32/104, site number in the village: 22 . A Przeworsk culture settlement; a village and a grave field from the early Middle Ages.

Geodetic coordinates of the excavation venue: X-390343.75/Y-519327.03. A Przeworsk culture settlement, an early-medieval settlement and a grave field.

Date of excavation: 9 VI 2018

Collection: Museum of the First Piasts at Lednica

Comments: a highly illegible coin

Literature: The Roman Imperial Coinage (further referred to as the RIC), vol. II, Trajan 60 (?) - regular issue of denarii in the Roman mint $^{24}$ (Fig. 1, photos 1a-b)

Lednica $2=\mathrm{C} 2-265-73$

Trajan's denarius, mint: Rome, $\mathrm{AD} 101-102$

Obverse: IMP(erator) CAES(ar) NERVA TRAIAN(us) AVG(ustus) GERM(anicus): bust of Trajan, laureate, right

Reverse: P(ontifex) M(aximus) TR(ibunicia) P(otestas) [CO(n)S(ul)] IIII $\mathrm{P}$ (ater) $\mathrm{P}$ (atriae): Mars, helmeted, naked except for cloak round waist, advancing right, holding transverse spear in right hand and trophy over left shoulder

24 At the same time, the mint in Rome issued quinarii (RIC II, Trajan 62-64). 
Diameter: $17-18.5 \mathrm{~mm}$

Weight: $2.66 \mathrm{~g}$

Axis: $6 \mathrm{~h}$

Excavation method: prospective metal detecting research

Location: (village/log ref. no.): Dziekanowice /7/2.AZP-50-32/104, site number in the village: 22 . A Przeworsk culture settlement; a village and a grave field from the early Middle Ages.

Geodetic coordinates of the excavation venue: X-390472.65\Y-519243.44. A Przeworsk culture settlement, an early-medieval settlement and a grave field.

Date of excavation: 13 X 2020

Collection: Museum of the First Piasts at Lednica

Comments: -

Literature: RIC II, Trajan 52

(Fig. 1, photos $2 \mathrm{a}-\mathrm{b}$ )

\section{Lednica $3=\mathrm{C} 2-282-19$}

Hadrian's denarius, mint: Rome, AD 130-138

Obverse: HADRIANVS - AVG(ustus) CO(n)S(ul) III P(ater) P(atriae): Hadrian's head without a wreath, right

Reverse: MONE - TA AVG(usti): Moneta standing to the left, holding scales and a cornucopia

Diameter: $16.7-17.8 \mathrm{~mm}$

Weight: $2.65 \mathrm{~g}$

Axis: $6 \mathrm{~h}$

Excavation method: prospective metal detecting research

Location (village/log ref. no.): Dziekanowice /9/2. AZP-50-32/104, site number in the village: 22. A Przeworsk culture settlement; a village and grave field from the early Middle Ages.

Geodetic coordinates of the excavation venue: X-390337.04/Y-519189.18 A Przeworsk culture settlement, an early-medieval settlement and a grave field. Date of excavation: 3 III 2019

Collection: Museum of the First Piasts at Lednica

Comments: a highly illegible coin

Literature: RIC II, Hadrian 256 = RIC II-3, Hadrian 2224

(Fig. 1, photos 3a-b) 
Lednica $4=\mathrm{C} 2-302-15$

Hadrian, denarius, mint: Rome, AC 137-138

Obverse: HADRIANVS - AVG(ustus) CO(n)S(ul) III P(ater) P(atriae): Hadrian's head without a wreath, right

Reverse: ANNON - A AVG(usti): a corn measuring vessel (modius) with ears of corn

Diameter: $16.0-16.4 \mathrm{~mm}$

Weight: $3.01 \mathrm{~g}$

Axis: $6 \mathrm{~h}$

Excavation method: prospective metal detecting research

Location (village/log ref. no.): Dziekanowice /9/2. AZP-50-32/104, site number in the village: 22 . A Przeworsk culture settlement; a village and a grave field from the early Middle Ages.

Geodetic coordinates of the excavation venue: X-390321.22/Y-519160.10

Date of excavation: 3 III 2019

Collection: Museum of the First Piasts at Lednica

Comments: -

Literature: RIC II, Hadrian 230a= RIC II-3, Hadrian 2318

(Fig. 1, photos $4 \mathrm{a}-\mathrm{b}$ )

Lednica $5=$ B3-140-1

Antoninus Pius, denarius, mint: Rome, AC 151-152

Obverse: ANTONINVS AVG(ustus) - PIVS P(ater) P(atriae) TR(ibunicia) P(otestate) XV : Antoninus Pius' head, laureate, right

Reverse: CO(n)S(ul) - IIII: Annona, standing on the left, holding two cornucopias in her right hand. Her left hand lies on a corn measuring vessel on a ship's prow, the rudder is next to the prow

Diameter: $17.1-18.1 \mathrm{~mm}$

Weight: $2.90 \mathrm{~g}$

Axis: $6 \mathrm{~h}$

Excavation method: prospective metal detecting research

Location (village/log ref. no.): Dziekanowice /44. AZP-50-32/98, site number in the village: 21 . A Przeworsk culture settlement and an early medieval settlement.

Geodetic coordinates of the excavation venue: X-390234.74/Y-518590.52

Date of excavation: 5 V 2019 
Collection: Museum of the First Piasts at Lednica

Comments: the reverse is hardly legible

Literature: RIC III, Antoninus Pius 204

(Fig. 1, photos 5a-b)

Lednica $6=\mathrm{C} 2-285-4$

Antoninus Pius, limes denarius, mint: limes, AD 140-143

Obverse: [ANTONINVS] AVG(ustus) [PI] - VS P(ater) P(atriae) $\mathrm{TR}($ ibunicia $)[\mathrm{P}($ otestate $) \mathrm{CO}(\mathrm{n}) \mathrm{S}(\mathrm{ul}) \mathrm{III}]$ : Antoninus Pius' head, laureate, right

Reverse: [AE]Q[VI] - TAS AVG(usti): Aequitas standing on the left, holding scales in her right and a sceptre in her left hand

Diameter: $17.4-17.8 \mathrm{~mm}$

Weight: $2.46 \mathrm{~g}$

Axis: $7 \mathrm{~h}$

Excavation method: prospective metal detecting research

Location (village/log ref. no.): Dziekanowice /7/2. AZP-50-32/104, site number in the village: 22 . A Przeworsk culture settlement and an early medieval settlement.

Geodetic coordinates of the excavation venue: X-390469.72/Y-519210.18

Date of excavation: 6 VII 2018

Collection: Museum of the First Piasts at Lednica

Comments: the coin is hardly legible

Literature: RIC III, Antoninus Pius 61c

(Fig. 1, photos 6a-b)

Lednica $7=\mathrm{C} 2-285-78$

Antoninus Pius, denarius, mint: Rome, AD 145-161

Obverse: [ANTONIN]VS - AVG(ustus) PI[VS] [P(ater) P(atriae)]: Antoninus Pius' head, laureate, right

Reverse: [TR(ibunicia) - POT(estate)] - CO(n)S(ul) IIII: Pax standing on the left, holding a twig in her right hand and a cornucopia in her left hand Diameter: $12.5-16.8 \mathrm{~mm}$

Weight: $1.48 \mathrm{~g}$ (entire coin), $0.04 \mathrm{~g}$ (fragment), $1.44 \mathrm{~g}$ (larger part)

Axis: $6 \mathrm{~h}$

Excavation method: prospective metal detecting research

Location (village/log ref. no.): Dziekanowice /7/2. AZP-50-32/104, site 
number in the village: 22. A Przeworsk culture settlement; a settlement and a grave field from the early Middle Ages.

Geodetic coordinates of the excavation venue: X-390468.72/Y-519205.68

Date of excavation: 4 VIII 2019

Collection: Museum of the First Piasts at Lednica

Comments: $2 / 3$ of the coin has survived; poorly legible

Literature: RIC III, Antoninus Pius 153c

(Fig. 1, photos 7a-b)

Lednica $8=\mathrm{C} 2-324-1$

Marcus Aurelius (Faustina II), denarius, mint: Rome, AD 161-176

Obverse: FAVSTINA - AVGVSTA: a bust of Faustina II wearing a tiara with her hair in a bun, right

Reverse: SAECVL[I] FELICIT(as): an ornamental, empty throne with children: Commodus and Antoninus

Diameter: $17.2-17.7 \mathrm{~mm}$

Weight: $2.74 \mathrm{~g}$

Axis: $5 \mathrm{~h}$

Excavation method: prospective metal detecting research

Location (village/log ref. no.): Dziekanowice /9/2. AZP-50-32/104, site number in the village: 22 . A Przeworsk culture settlement; a settlement and a grave field from the early Middle Ages.

Geodetic coordinates of the excavation venue: X-390434.46/Y-519114.13

Date of excavation: 24 II 2019

Collection: Museum of the First Piasts at Lednica

Comments: the reverse is heavily used

Literature: RIC III, Marcus Aurelius (Faustina II) 710

(Fig. 1, photos 8a-b)

Lednica $9=\mathrm{C} 2-283-5$

Marcus Aurelius (Lucilla), denarius, mint: Rome, AD 164-169

Obverse: LVCILLAE AVG(ustae) ANTONINI AVG(usti) F(ilia): Lucilla's bust (in drapery), wavy hair, fastened in a bun, right

Reverse: VES-TA (caption poorly visible): Vesta in a long robe, turned to the left, standing in front of an altar with the lights on, holding a simpulum in her right hand and a palladium in her left hand

Diameter: $17.5-18.1 \mathrm{~mm}$ 
Weight: $3.17 \mathrm{~g}$

Axis: $6 \mathrm{~h}$

Excavation method: prospective metal detecting research

Location (village/log ref. no.): Dziekanowice /7/2. AZP-50-32/104, site number in the village: 22 . A Przeworsk culture settlement; a settlement and a grave field from the early Middle Ages.

Geodetic coordinates of the excavation venue: X-390355.19/Y-519207.56

Date of excavation: 2 V 2018

Collection: Museum of the First Piasts at Lednica

Comments: the reverse is heavily used

Literature: RIC III, Marcus Aurelius (Lucilla) 788

(Fig. 1, photos 9a-b)

Lednica $10=\mathrm{C} 2-324-7$

Issuer unknown, denarius subaeratus, mint: ?

Obverse: ?

Reverse: a standing female figure with a horn of plenty

Diameter: $17.8-18.2 \mathrm{~mm}$

Weight: $2.63 \mathrm{~g}$

Axis: $6 \mathrm{~h}$

Excavation method: prospective metal detecting research

Location (village/log ref. no.): Dziekanowice, in the vicinity of the AZP50-32/104, site number in the village: 22 . A Przeworsk culture settlement; a settlement and a grave field from the early Middle Ages.

Geodetic coordinates of the excavation venue: X-390411.43/Y-519111.10

Date of excavation: 3 III 2019

Collection: Museum of the First Piasts at Lednica

Comments: the coin is highly corroded, partly melted; illegible

Literature: -

(Fig. 1, photos 10a-b)

Lednica $11=$ C2 $-250-6$

Time of Antoninus Pius (?), denarius, mint: ?

Obverse: ?

Reverse: $[\ldots]$ a sitting female figure, turned to the left

Diameter: $16.6-17.7 \mathrm{~mm}$

Weight: $1.94 \mathrm{~g}$ 


\section{Axis: $7 \mathrm{~h}$}

Excavation method: prospective metal detecting research

Location (village/log ref. no.): Dziekanowice /3. AZP-50-32/107, site number in the village: 26 . Settlement point: the early Bronze Age, a settlement from the early Middle Ages.

Geodetic coordinates of the excavation venue: X-390727.68/Y-519298.84 Date of excavation: 17 IV 2019

Collection: Museum of the First Piasts at Lednica

Comments: the coin is poorly legible

Literature: -

(Fig. 1, photos 11a-b)

Index of abbreviations

RIC II: The Roman Imperial Coinage, Vol. II, eds. by H.Mattingly, E.A. Sydenham, London 1926

RIC II-3: The Roman Imperial Coinage, Vol. II - Part 3: From AD 117-138 Hadrian, ed. by R.A. Abdy, with a section on medallions by P.F. Mittag, London 2019

RIC III: The Roman Imperial Coinage, Vol. III, eds. by H.Mattingly, E.A. Sydenham,London 1930

\section{Bibliography}

\section{Sources}

The Roman Imperial Coinage, Vol. II, eds. by H.Mattingly, E.A. Sydenham,London 1926.

The Roman Imperial Coinage, Vol. II - Part 3: From AD 117-138 Hadrian, ed. by R.A. Abdy, with a section on medallions by P.F. Mittag, London 2019.

The Roman Imperial Coinage, Vol. III, ed. by H. Mattingly, E.A. Sydenham, London 1930.

\section{Literature}

Balbuza K., Studia Lednickie 19 (2020), pp. 261-273.

Dymowski A., Znaleziska monet rzymskich rejestrowane w pierwszych latach XXI wieku. Aspekty źródłoznawcze, Zielona Góra 2011. 
Dymowski A. Nummi serrati, bigati et alii. Coins of the Roman Republic in East-Central Europe North of the Sudetes and the Carpathians, Warsaw 2016.

Kostyrko M., Kowalczyk A., Żuk L., Projekt Lednica "Razem dla ratowania zabytków". Sprawozdanie za rok 2018 (Lednica Project "Together to Save the Heritage". A Report on Work Undertaken in 2018), Studia Lednickie 18 (2019), pp. 323-333 .

Miechowicz Ł., By pewniej i szybciej przenióst się na tamten świat... Pieniądz jako element praktyk pogrzebowych na Mazowszu, Podlasiu i w Małopolsce w średniowieczu i czasach nowożytnych, [in:] "In silvis, campis... et urbe". Średniowieczny obrzadek pogrzebowy na pograniczu polsko-ruskim, ed. by S. Cygan, M. Glinianowicz, P.N. Kotowicz, Rzeszów-Sanok 2010, pp. 331-356.

Monitor Polski 50 (1994), item 421: http://isap.sejm.gov.pl/isap.nsf/DocDetails. xsp?id=WMP19940500421.

Nielsen S., Roman Denarii in Denmark - an Archaeological Approach, Nordisk Numismatisk Årsskrift 88 (1987), p. 147-167.

Nummus bonum fragile est. Groby z monetami wczesnośredniowiecznego cmentarzyska $w$ Dziekanowicach, vol. 1-2, ed. by J. Wrzesiński, Lednica 2016 (Fontes. Biblioteka Studiów Lednickich, series B1, vol. 7: 1-2).

Ostrów Lednicki. Rezydencjonalno-stołeczny ośrodek pierwszych Piastów, ed. by Z. Kurnatowska, A. Wyrwa, Warsaw 2016.

Steuer H., Obolus, [in:] Reallexikon der Germanischen Altertumskunde 21 (2002), pp. 498-515.

Suchodolski S., Obol zmarlych (monety i pieniądz kruszcowy) na cmentarzysku w Dziekanowicach, stan. 22, [in:] Nummus bonum fragile est, Vol. 1, pp. 157-196.

Wawrzyniak M., Zbiór fibul z okresu wpływów rzymskich pozyskanych w trakcie badań powierzchniowych zrealizowanych w ramach „Projekt Lednica. Razem dla ratowania zabytków” w latach 2018-2022, Studia Lednickie XX, 2021 (in print). Wrzesiński J., Archeologia dziekanowickich grobów z monetami, [in:] Nummus bonum fragile est, Vol. 1, pp. 13-156.

Zapolska A., Denary rzymskie znajdowane w kontekstach wczesnośredniowiecznych na ziemiach polskich, Wiadomości Numizmatyczne 51 (2007), pp. 149-178. 


\section{Summary}

Roman coin finds from vicinity of Ostrów Lednicki. Lednica Project "Together to Save the Heritage" (2018-2022)

The article presents finds of Roman coins from the area located in the immediate vicinity of Ostrów Lednicki island, found in the years 2018-2022. The coins date back to the Roman cultural influence in Poland and perhaps, in combination with other finds from this area, dating back to the same period, they prove the existence of the Roman-era communities round here.

Translated by Ewa Dratwa

Nadesłany: 13 III 2021

Nadesłany po poprawkach: 7 VIII 2021

Zaakceptowany: 17 IX 2021

Dr hab. Katarzyna Balbuza, prof. UAM

Uniwersytet im. Adama Mickiewicza w Poznaniu

Wydział Historii

ul. Uniwersytetu Poznańskiego 7

61-614 Poznań

e-mail: balbuza@amu.edu.pl 
Fig. 1. Dziekanowice, Łubowo commune, Gniezno county. Roman coins. Photo by M. Jóźwikowskaa
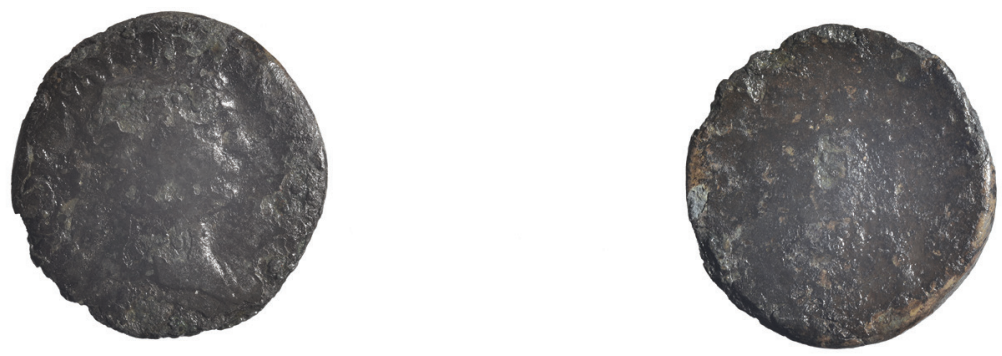

Lednica $1=\mathrm{C} 2-222-6$
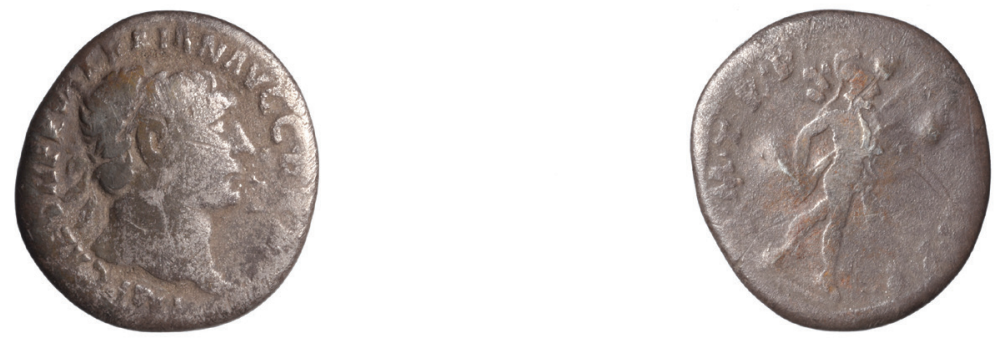

Lednica $2=\mathrm{C} 2-265-73$
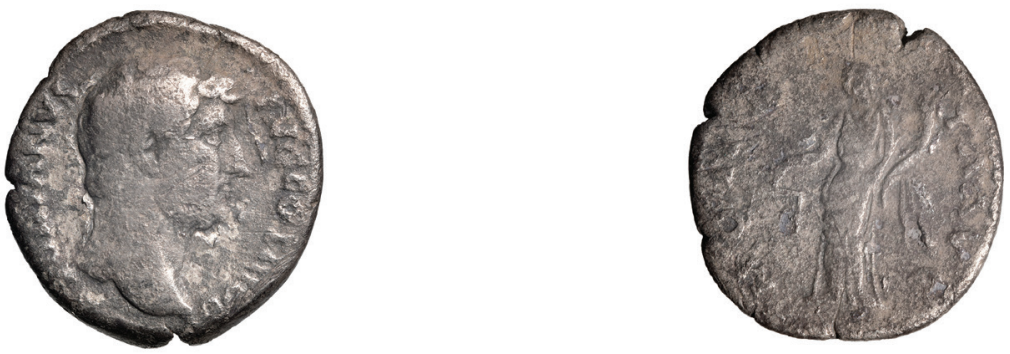

Lednica $3=$ C2-282-19
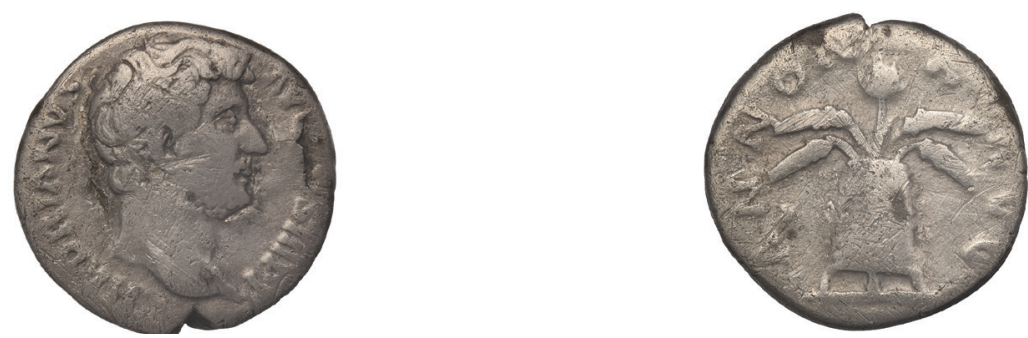

$$
\text { Lednica } 4=\text { C2-302-15 }
$$

25 The pictures of the coins are not scaled $1: 1$. 

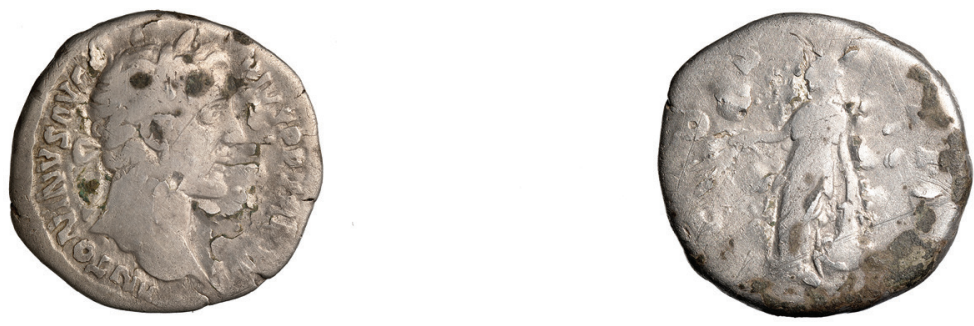

Lednica 5 = B3-140-1
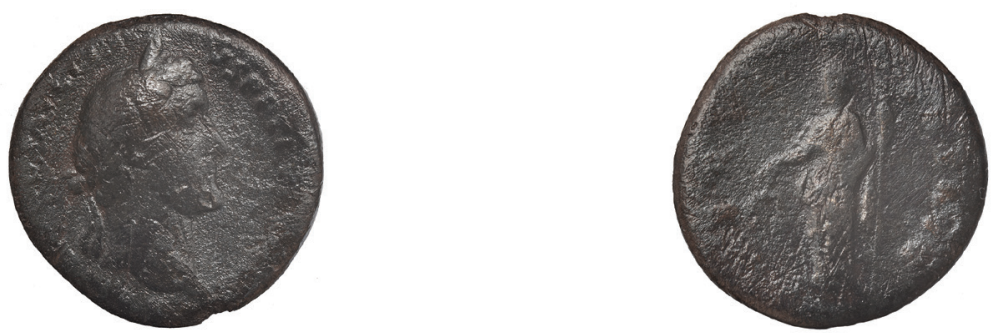

Lednica $6=\mathrm{C} 2-285-4$
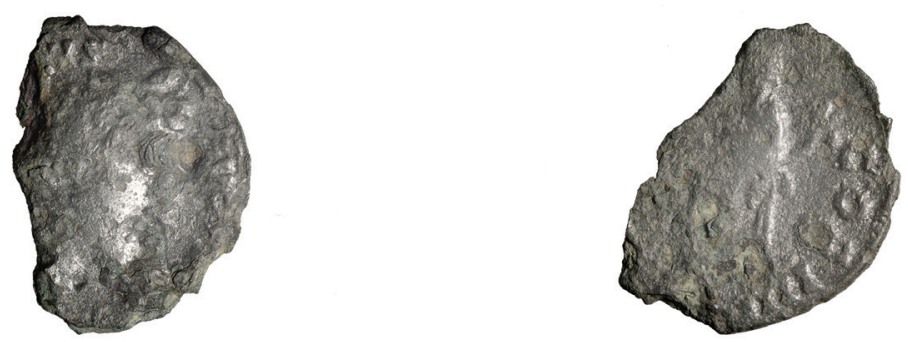

Lednica $7=\mathrm{C} 2-285-78$
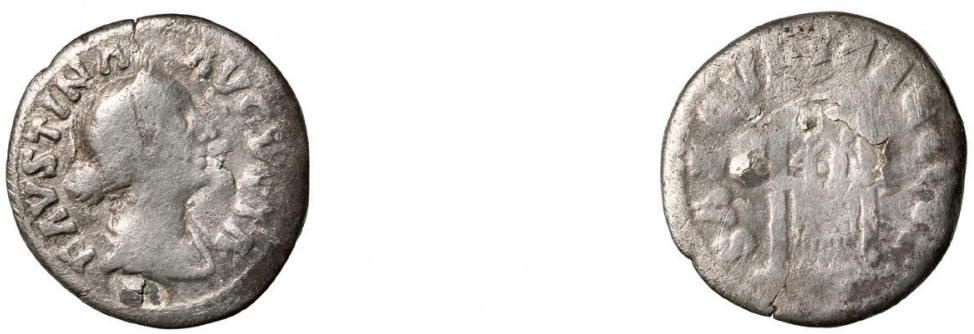

Lednica $8=\mathrm{C} 2-324-1$ 

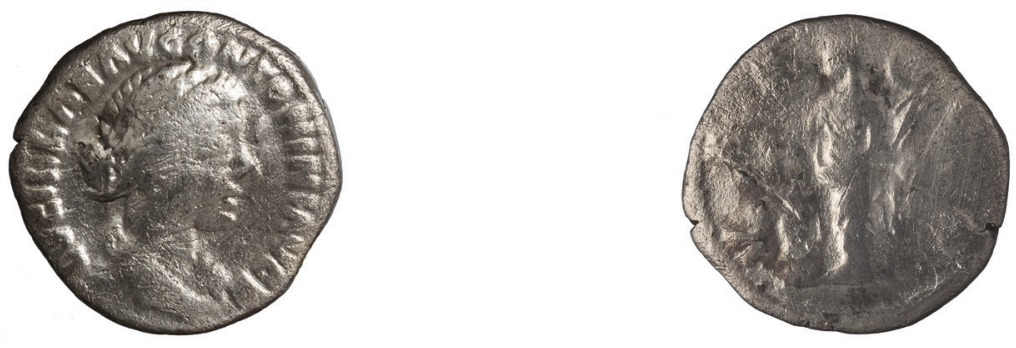

Lednica $9=\mathrm{C} 2-283-5$
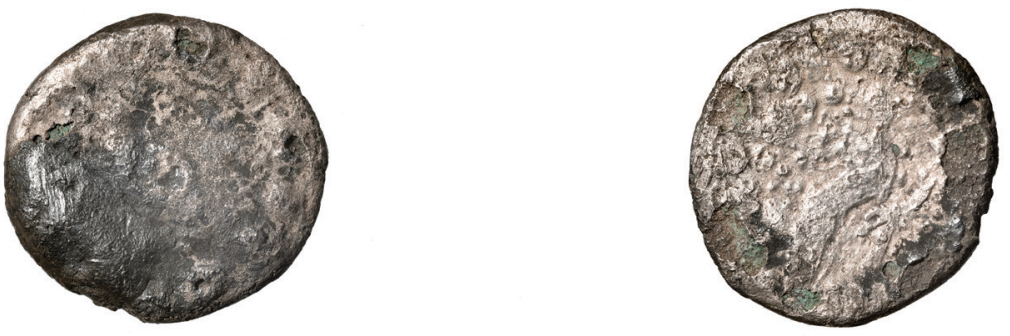

Lednica $10=\mathrm{C} 2-324-7$
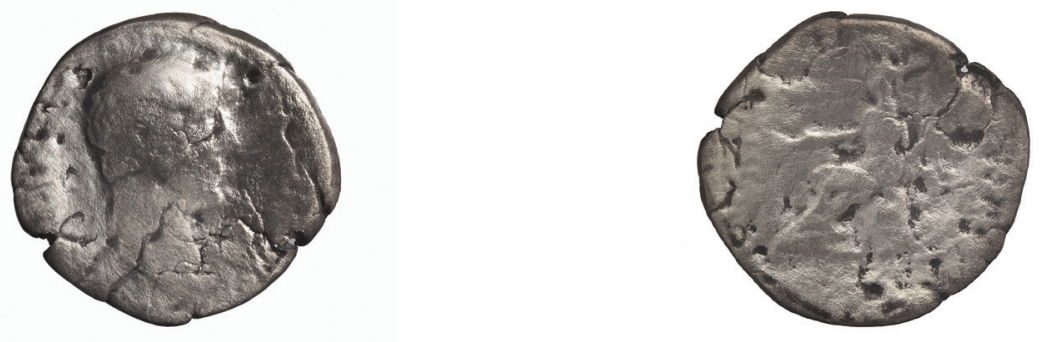

Lednica $11=\mathrm{C} 2-250-6$ 
Fig. 2. Orthophotomap with the dispersion of finds of Roman coins together with the area of recorded archaeological sites. Ed. by M. Kostyrko

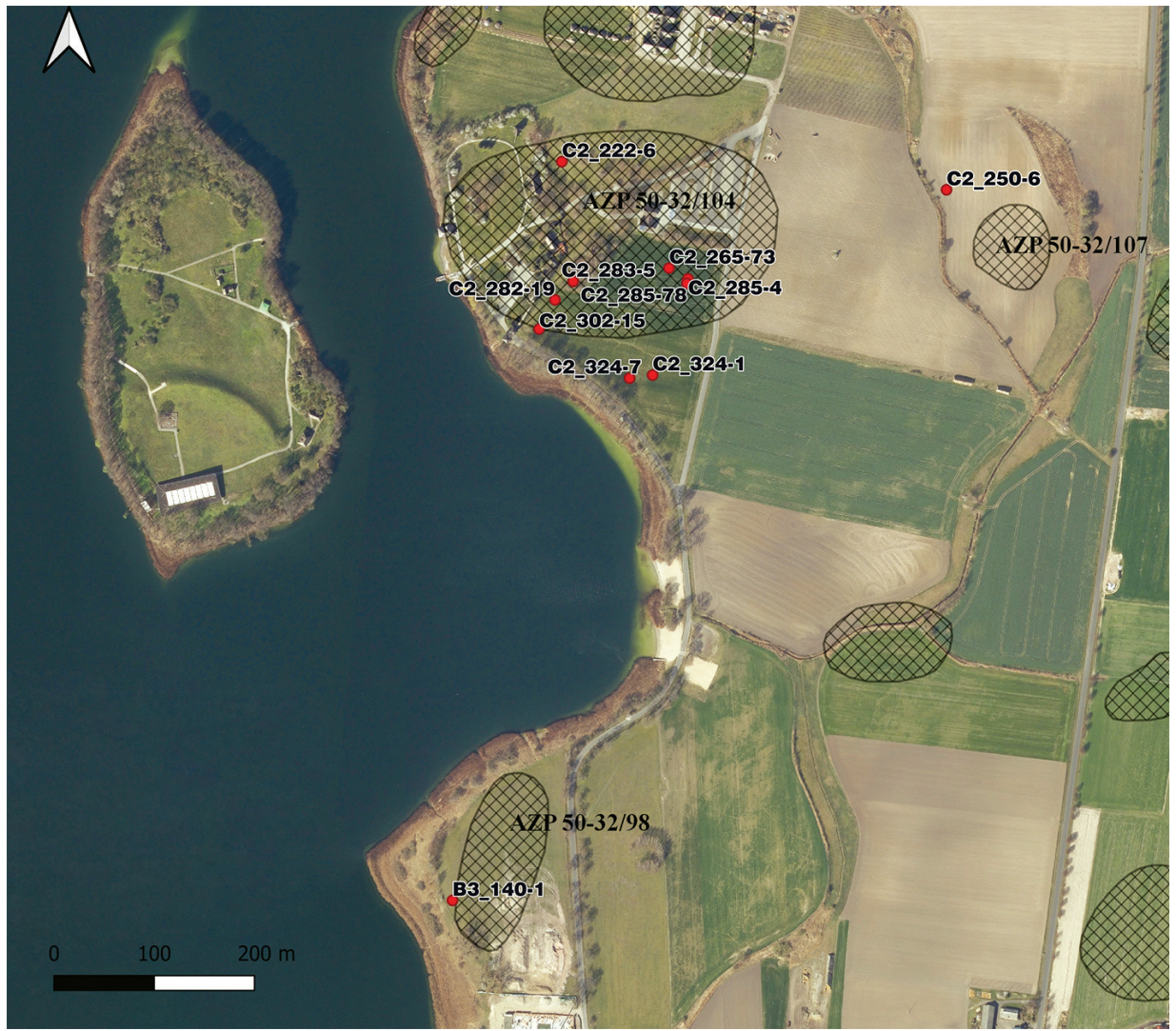

